\title{
Effects of Multi-Micronutrient Mixture on Growth, Yield and Quality of the Summer Pearl Millet (Pennisetum glaucum L.)
}

\author{
V.H. Kadivala*, V.P. Ramani and P.K. Patel \\ Micronutrient Project (ICAR), Anand Agricultural University, Anand 388 110, Gujarat, India \\ *Corresponding author
}

\begin{tabular}{|l}
\hline Key w or d s \\
Multi-micronutrient \\
mixture, Summer \\
pearl millet, Yield, \\
Crude protein
\end{tabular}

\section{Keywords} mixture, Summer pearl millet, Yield, de protein

\section{Introduction}

Micronutrient deficiencies are becoming increasingly common in agriculture as a result of higher levels of removal by ever-moreproductive crops combined with breeding for higher yields, at the expense of micronutrient acquisition efficiency. The, systematic studies for delineation of micronutrients in Gujarat reported $25 \% \mathrm{Zn}$ and $25 \% \mathrm{Fe}$ in different soils of Gujarat. The deficiency of Mn was also found to encores in some parts of the state (Anon. 2014-15). Pearl millet (Pennisetum glaucum L.) is one of the major coarse grain crops and is considered to be a poor man's food. It is the most drought tolerant crop among cereals and millets.

The diminishing use of micronutrients has lead to the occurrences of widespread deficiency of micronutrients especially of $\mathrm{Zn}$ and $F e$ which warrants the need for research on $\mathrm{Zn}$ and $\mathrm{Fe}$ on their usage individually and in mixtures as foliar/soil application. Therefore, the experiment was planned to study the effects of multi-micronutrient mixture on growth, yield and quality of the pearl millet. 


\section{Materials and Methods}

A field experiment was conducted at Main forage Research Station, AAU, Anand during summer season of the year 2017 for studying effects of multi-micronutrients mixture in improving production of summer pearl millet (Pennisetum glaucum L.) (GHB-558).The treatment was comprised of $\mathrm{T}_{1}$-control, foliar spray treatments: $\mathrm{T}_{2}$-multi-micronutrient mixture grade-I (general), $\mathrm{T}_{3}$-multimicronutrient mixture grade-II (for $\mathrm{Zn}$ deficiency), $\mathrm{T}_{4}$-multi-micronutrient mixture grade-III (for $\mathrm{Fe}$ deficiency), $\mathrm{T}_{5}$-multimicronutrient mixture grade-IV (for $\mathrm{Zn} \& \mathrm{Fe}$ deficiency) and soil application treatments: $\mathrm{T}_{6}$-multi-micronutrient mixture grade- $\mathrm{V}$ and $\mathrm{T}_{7}$-soil application of micronutrients as per soil test value (STV). The multi-micronutrient mixture grades having concentration shown in table 1 were prepared on the basis of average removal of micronutrients by different crops (grades I and IV) and other grades (II to IV) on the basis of wide spread occurrences of $\mathrm{Zn}$ or $\mathrm{Fe}$ or $\mathrm{Zn}$ and $\mathrm{Fe}$ deficiencies in soils of Gujarat. The multi-micronutrients mixture facilitate the application of the wide range of plant nutrients in the proportion and to suit the specific requirements of a crop in different stages of growth, and are more relevant under site specific nutrient management practices. Therefore, there is a need to promote balanced fertilization for which use of appropriate multi-micronutrient mixture grades would play a big role to improve nutrients use efficiency and enhance crops productivity for food and nutritional security.

The rate of application of different grades for foliar spray was kept $1 \%$. The foliar application was made during crop growth period with three sprays at 15,30 and 45 DAT (Days after Transplanting) of the crop and the soil application of grade- $\mathrm{V}$ was $20 \mathrm{~kg}$ $\mathrm{ha}^{-1}$ as basal. The treatments were tested against the standard recommended application of micronutrients $\left(50 \mathrm{~kg} \mathrm{FeSO}_{4} .5 \mathrm{H}_{2} \mathrm{O} \mathrm{ha}^{-1}\right.$ and $\left.40 \mathrm{~kg} \mathrm{MnSO}_{4} \cdot 3 \mathrm{H}_{2} \mathrm{O} \mathrm{ha}^{-1}\right)$ on soil test value i.e. STV basis and control as well.

The treatments were replicated four times in a randomized block design. The soil of the experimental field was Typic Ustochrepts, loamy sand in texture and had $\mathrm{pH}_{1: 2.5}-7.96$, $\mathrm{EC}_{1: 2.5^{-}} 0.44 \mathrm{dS} \mathrm{m}^{-1}$, organic carbon-3.65 $\mathrm{g} \mathrm{kg}^{-}$ ${ }^{1}$, available $\mathrm{N}-188 \mathrm{~kg} \mathrm{ha}^{-1}$, available $\mathrm{P}_{2} \mathrm{O}_{5^{-}}$ $80.70 \mathrm{~kg} \mathrm{ha}^{-1}$, available $\mathrm{K}_{2} \mathrm{O}-301.6 \mathrm{~kg} \mathrm{ha}^{-1}$, available $\mathrm{S}-9.24 \mathrm{mg} \mathrm{kg}{ }^{-1}, \mathrm{Fe}-4.20 \mathrm{mg} \mathrm{kg}^{-1}$, Mn-4.39 mg kg-1, Zn-1.20 mg kg ${ }^{-1}, \mathrm{Cu}-0.59$ $\mathrm{mg} \mathrm{kg}$ and B-0.37 mg kg${ }^{-1}$. Before field preparation the pearl millet nursery was raised at Model laboratory, Micronutrient Research Project (ICAR) during February, 2017. The soil was collected from the experimental site and filled in micro plot and then pearl millet seed were broadcasted and nursery was prepared as per recommendation. After fertilization, pre-transplanting irrigation was given to the experimental plot. The uniform healthy seedlings of pearl millet cv. GHB558 having an age of twenty days were uprooted after applying the irrigation to the nursery and one seedling per hill was transplanted at $45 \mathrm{~cm} \times 10 \mathrm{~cm}$ spacing.

The field observation on plant height, ear head length, no. of effective tillers, test weight, grain and straw yield were recorded. Plant height was recorded at 30, 45 DAT and at harvest for five randomly selected tagged plants in each net plot and average was calculated and recorded separately. The ear head length from the some randomly tagged five plants was used for studying this character. Length of five ear heads was measured in centimetre from the cut end of the ear head to the tip of the ear head and mean was worked out and recorded plot wise. Number of effective tillers per meter row length was recorded from net plot area at harvesting of crop. From the composite samples of grain of each net plot, 1000 seeds 
were counted and the weight was recorded in $\mathrm{g}$ for all the experimental plots. The produce of each net plot was threshed separately, cleaned and the grain yield was recorded in $\mathrm{kg}$ per net plot and then converted into $\mathrm{kg}$ ha 1. Straw yield was obtained by subtracting the grain yield of each net plot from their respective total dry matter (Above ground) yield and computed in terms of $\mathrm{kg} \mathrm{ha}^{-1}$ and converted it on hectare basis. The percentage protein of grains was worked out by Lowry's method (Lowry's et al., 1951). The soil samples drawn from the experimental field at harvest were analysed for available micronutrients by extracting with $0.005 \mathrm{M}$ DTPA (Lindsay and Norvell, 1978) and the contents were determined on atomic absorption spectrophotometer. Boron content in soil was determined by spectrophotometer using azomethine-H by hot water method (Datta et al., 2002). The plant samples were taken for determination of contents of micronutrients. Then samples were dried in paper bags at $70^{\circ} \mathrm{C}$ in hot air oven till constant weight and ground in stainless steel grinder and were digested in di-acid mixture of $\mathrm{HNO}_{3}: \mathrm{HClO}_{4}(4: 1)$ as per procedure outlined by Lindsay and Norvell (1978). Boron content in grain and straw samples was analysed by dry ashing method (Page et al., 1982).

\section{Results and Discussion}

\section{Growth}

The effect of multi-micronutrient mixture on plant height of pearl millet at 30, 45 DAT and at harvest are presented in table 2. The little improvement in plant height of pearl millet was noticed at 30, 45 DAT and at harvest due to different treatments of multi-micronutrients mixture, but did not reach the level of significance.

The data on ear head length, no. of effective tillers, test weight of grain and harvest index of pearl millet for different treatments are presented in table 3. An appraisal of data revealed that the three foliar spray of $1 \%$ multi-micronutrient mixture Grade-IV (grade for $\mathrm{Zn} \&$ Fe deficiency) at 15, 30 and 45 DAT recorded significantly the higher ear head length $(23.40 \mathrm{~cm})$ of pearl millet, over control. However, the $\mathrm{T}_{5}$ was at par with soil application $\left(\mathrm{T}_{6}\right)$ of $20 \mathrm{~kg} \mathrm{ha}{ }^{-1}$ multimicronutrient mixture (Grade-V) and STV (Soil Test Value) $50 \mathrm{~kg} \mathrm{FeSO} 4.5 \mathrm{H}_{2} \mathrm{O} \mathrm{ha}{ }^{-1}$ and $40 \mathrm{~kg} \mathrm{MnSO}_{4} .3 \mathrm{H}_{2} \mathrm{O} \mathrm{ha}^{-1}$ which was also resulted in increase of ear head length. The increase in head length with the application of multi-micronutrient mixture Grade-IV might be due to Grade-IV is deficient in $\mathrm{Zn}$ and $\mathrm{Fe}$ and the soil was low in available Fe status, their supplementation in balanced form along with other micronutrients might have played an important role to mitigate the hidden hunger of the crop for micronutrients. Although the micronutrients are required in a small quantity, there supplementation during the crop growth help in better utilization of all other nutrients which in turn result in increase of crop growth of maize (Patel et al., 2009). Further, the results revealed that there were no significant effect of multi-micronutrient mixture on No. of effective tillers, test weight and harvest index of pearl millet.

\section{Yield}

Foliar application of $1 \%$ multi-micronutrient mixture Grade-III (grade for Fe deficiency) at 15, 30 and 45 DAT recorded significantly higher grain yield of pearl millet $\left(2291 \mathrm{~kg} \mathrm{ha}^{-}\right.$ ${ }^{1}$ ), wherein an overall increase of $299 \mathrm{~kg} \mathrm{ha}^{-1}$ was observed over control (1992 kg ha-1). It was remained at par with three foliar spray of $1 \%$ multi-micronutrient mixture Grade-II (grade for $\mathrm{Zn}$ deficiency) and Grade-IV (for Zn \& Fe deficiency) and soil application of Grade-V ( $\left.\mathrm{T}_{6}\right)$ and Soil Test Value (STV) treatment. The increase in grain yield of pearl millet could be attributed to greater response 
of applied Grade-III (Fe deficiency) may be due to experimental soil was deficient in available Fe. The effect of $\mathrm{Fe}$ on grain yield can also be explained on the basis of relatively higher doses of $\mathrm{Fe}$ tended to produce more vegetative growth resulting from efficient utilization of nutrients, water, radiation and increased metabolic activities followed by increased translocation toward yield contributing characters, which might have led to significant increase in grain yield. Further, the addition of the micronutrients also helps in better utilization of the major nutrients to produce higher yield of crops. Earlier workers, Chandrakumar et al., (2004), Singh and Ram (2005) and Esfahani et al., (2014) have also reported similar increase in yield of wheat and rice due to $\mathrm{Fe}$ and/or $\mathrm{Zn}$ application under different agro-climatic conditions. Patel and Singh (2010) also found the beneficial effect of multi-micronutrients could be the balanced nutrition of the crops and thereby improved crop growth as well as yield.

The application of micronutrients of $50 \mathrm{~kg}$

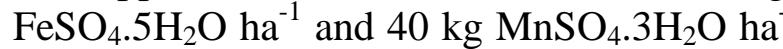
1 as per STV (Soil Test Value) increased straw (4906 kg ha ${ }^{-1}$ ) and total (7138 kg ha-1) yield of pearl millet was significantly higher over control. The maximum increase of 702 $\mathrm{kg} \mathrm{ha}{ }^{-1}$ and $942 \mathrm{~kg} \mathrm{ha}{ }^{-1}$ was observed respectively, over control. However, in case of straw yield it was at par with $\mathrm{T}_{3}$ (Grade-II), $\mathrm{T}_{4}$ (Grade-III) and soil application (Grade-V), while total yield was at par with $\mathrm{T}_{3}$ (GradeII), $\mathrm{T}_{4}$ (Grade-III), $\mathrm{T}_{5}$ (Grade-IV) and $\mathrm{T}_{6}$ (Grade-V) (Table 4). It's might be due to the favourable effect of applied Fe on these growth parameters may be ascribed to synergetic effect of $\mathrm{Fe}$ on most of the photosynthesis, physiological and metabolic processes of the plant followed by increased translocation toward yield contributing characters, which might have led to significant increase in straw yields of rice (Ali et al., 2014, Abid et al., 2002 and Keram et al., 2012).

Since, site of experiment was categorized as low with regard to soil available $\mathrm{Mn}$, its supplementation through soil application might have increase that Mn-containing enzymes viz. alcohol dehydrogenase, carbonic anhydrase, alkaline phosphatase, phospholipase, carboxypeptidase, and RNA polymerase which improve the photosynthetic activity and translocation.

Good responses to $\mathrm{Mn}$ fertilization in terms of attaining high crop yield on Mn-deficient soils have been reported by (Nayyer et. al., 1985; Soni 1996; Sharma and Bapat 2000; Bansal and Khurana 2002; Varshney et al., 2008; Dhaliwal et al., 2009).

Khan et al., (2008) also reported improvements in wheat yield with soil application of $\mathrm{Mn}$. They indicated that the apparent mechanism for improvements in wheat yield due to application of Mn might be due to the increase in leaf area index, providing an improved resource generating base for the crop i.e. an improved carbohydrate source. The consequence of this improved source is the improvement in overall biomass and consequently improvements in yield components of the crop.

\section{Crude protein}

The mean data regarding protein content in pearl millet grain as influenced by multimicronutrient mixture application are presented in table 5 .

The result revealed that there was no significant effect of application of multimicronutrient mixture on protein content of pearl millet. 
Table.1 Composition of different grades

\begin{tabular}{|l|l|c|c|c|c|c|}
\hline Sr. & \multicolumn{1}{|c|}{ Grade } & \multicolumn{5}{|c|}{ Content (\%) } \\
\cline { 3 - 7 } No. & & $\mathrm{Fe}$ & $\mathrm{Mn}$ & $\mathrm{Zn}$ & $\mathrm{Cu}$ & $\mathrm{B}$ \\
\hline 1. & LF Grade I (General) & 2 & 0.5 & 4.0 & 0.3 & 0.5 \\
\hline 2. & LF Grade II (For Zn deficiency) & 2 & 0.5 & 8.0 & 0.5 & 0.5 \\
\hline 3. & LF Grade III (For Fe deficiency) & 6 & 1.0 & 4.0 & 0.3 & 0.5 \\
\hline 4. & LF Grade IV (For Zn \& Fe deficiency) & 4 & 1.0 & 6.0 & 0.5 & 0.5 \\
\hline 5. & LF Grade V (Soil application) & 2 & 0.5 & 5.0 & 0.2 & 0.5 \\
\hline
\end{tabular}

Table.2 Effect of multi micronutrient mixture on plant height $(\mathrm{cm})$ of pearl millet

\begin{tabular}{|c|c|c|c|}
\hline \multirow[t]{2}{*}{ Treatments } & \multicolumn{3}{|c|}{ Period } \\
\hline & $\begin{array}{c}30 \\
\text { DAT }\end{array}$ & $\begin{array}{c}45 \\
\text { DAT }\end{array}$ & $\begin{array}{c}\text { At } \\
\text { Harvest }\end{array}$ \\
\hline$T_{1}$ : Control & 73.3 & 117 & 121.80 \\
\hline$T_{2}:$ Grade-I (FS) & 73.1 & 118 & 125.10 \\
\hline$T_{3}:$ Grade-II (FS) & 73.9 & 119 & 125.85 \\
\hline $\mathbf{T}_{4}$ : Grade-III (FS) & 73.3 & 119 & 125.33 \\
\hline$T_{5}:$ Grade-IV (FS) & 72.8 & 118 & 126.30 \\
\hline$T_{6}:$ Grade-V (SA) & 73.9 & 123 & 126.30 \\
\hline$T_{7}:$ STV & 77.2 & 122 & 126.05 \\
\hline SEm \pm & 1.3 & 1.8 & 1.78 \\
\hline CD at $5 \%$ & NS & NS & NS \\
\hline CV (\%) & 3.5 & 3.0 & 2.85 \\
\hline
\end{tabular}

Table.3 Effect of multi micronutrient mixture on growth of pearl millet

\begin{tabular}{|c|c|c|c|c|}
\hline Treatments & $\begin{array}{l}\text { Ear head } \\
\text { length }(\mathrm{cm})\end{array}$ & $\begin{array}{l}\text { No. of tillers } \\
\text { per meter row } \\
\text { length }\end{array}$ & $\begin{array}{l}\text { Test weight } \\
\text { (g) }\end{array}$ & $\begin{array}{c}\text { Harvest } \\
\text { index }(\%)\end{array}$ \\
\hline$T_{1}$ : Control & 20.98 & 24.63 & 7.78 & 32.13 \\
\hline $\mathrm{T}_{2}:$ Grade-I (FS) & 22.18 & 25.42 & 7.90 & 31.72 \\
\hline $\mathrm{T}_{3}$ : Grade-II (FS) & 22.45 & 25.26 & 8.18 & 32.35 \\
\hline $\mathrm{T}_{4}$ : Grade-III (FS) & 22.18 & 25.24 & 8.05 & 33.07 \\
\hline T $_{5}$ :Grade-IV (FS) & 23.40 & 28.00 & 8.14 & 32.97 \\
\hline$T_{6}:$ Grade-V (SA) & 23.15 & 25.70 & 8.13 & 32.04 \\
\hline $\mathbf{T}_{7}: \mathrm{STV}$ & 22.50 & 24.09 & 8.15 & 31.27 \\
\hline SEm \pm & 0.34 & 1.07 & 0.13 & 1.03 \\
\hline CD at $5 \%$ & 1.00 & NS & NS & NS \\
\hline CV (\%) & 3.01 & 8.36 & 3.29 & 6.41 \\
\hline
\end{tabular}


Table.4 Effect of multi micronutrient mixture on yield $\left(\mathrm{kg} \mathrm{ha}^{-1}\right)$ of pearl millet

\begin{tabular}{|c|c|c|c|}
\hline Treatments & Grain & Straw & Total \\
\hline $\mathbf{T}_{1}$ : Control & 1992 & 4204 & 6196 \\
\hline $\mathrm{T}_{2}:$ Grade-I (FS) & 2014 & 4345 & 6359 \\
\hline $\mathbf{T}_{3}:$ Grade-II (FS) & 2214 & 4650 & 6863 \\
\hline T $_{4}$ : Grade-III (FS) & 2291 & 4654 & 6945 \\
\hline$T_{5}:$ Grade-IV (FS) & 2268 & 4615 & 6883 \\
\hline T $_{6}:$ Grade-V (SA) & 2260 & 4792 & 7052 \\
\hline$T_{7}:$ STV & 2232 & 4906 & 7138 \\
\hline SEm \pm & 63 & 140 & 141 \\
\hline CD at $5 \%$ & 187 & 417 & 419 \\
\hline CV (\%) & 5.8 & 6.1 & 4.1 \\
\hline
\end{tabular}

Table.5 Effect of multi micronutrient mixture on protein content of pearl millet

\begin{tabular}{|c|c|}
\hline Treatments & Protein content (\%) \\
\hline$T_{1}:$ Control & 1.97 \\
\hline $\mathbf{T}_{2}:$ Grade-I (FS) & 1.90 \\
\hline$T_{3}:$ Grade-II (FS) & 2.00 \\
\hline T $_{4}:$ Grade-III (FS) & 1.91 \\
\hline T $_{5}$ : Grade-IV (FS) & 1.81 \\
\hline$T_{6}:$ Grade-V (SA) & 1.94 \\
\hline $\mathrm{T}_{7}: \mathrm{STV}$ & 1.98 \\
\hline SEm \pm & 0.06 \\
\hline CD at $5 \%$ & NS \\
\hline CV (\%) & 6.17 \\
\hline
\end{tabular}

In conclusion, the results of the present study indicated that from yield point of view, soil application as per STV (Soil Test Value) or application of multi-micronutrient mixture (except Grade-I) were found significantly superior over control. Foliar application and soil application of multi-micronutrient mixture grades found comparable with STV indicated that chemical load can reduce without affecting the yield of pearl millet.

Thus, the finding of the present study suggested that agronomic approach for yield and micronutrients concentration enhancement could be better accomplished by its supplementation through soil (basal) or foliar application at 15, 30 and 45 DAT (Days after Transplanting) of summer pearl millet.

\section{References}

Abid, M., Ahmad, N., Jahangir, M. and Ahmad, I. (2002) Effect of Zn, Fe and $\mathrm{Mn}$ on growth and yield of rice (Oryza sativa L.). Pakistan Journal of Agricultural Science39, 101-103.

Ali, H., Hasnain, Z., Shahzad, A.N. and Sarwar, N. (2014) Nitrogen and zinc interaction improves yield and quality of submerged basmati rice (Oryza sativa L.). Notulae Botanicae Horti Agrobotanici Cluj-Napoca42, 372- 
379.

Anonymous, (2014-2015). Annual Progress Report, Micronutrient Research Project (ICAR), AAU, Anand.

Bansal, R.L. and Khurana, M.P.S. (2002) Foliar application of $\mathrm{Zn}$ and $\mathrm{Mn}$ Fertilizers on Yield and Yield attributes of wheat. Journal of Indian Society of Soil Science, 45, 35-39.

Chandrakumar, K., Halepyati, A.S., Desai, B.K. and Pujari, B.T. (2004) Grain yield, dry matter production and its portioning in wheat var. DWR-195 as influenced by organics, macro, micronutrients and method of application. Karnataka Journal of Agricultural Science 17, 10-16.

Datta, S.P., Rattan, R.K., Suribabu, K. and Datta, S.C. (2002) Fractionation and colorimetric determination of boron in soils.Journal of Plant Nutrition and Soil Science 165, 179-184.

Dhaliwal, S.S., Sadana, U.S., Manchanda, J.S. and Dhadli, H.S. (2009) Biofortification of wheat grains with Manganese in Typic Ustochrept soils of Punjab. Indian Journal of Fertilizers5, 13-16 \& 19-20.

Esfahani, A.A., Pirdashti, H. and Yousuf, N. (2014) Effect of $\mathrm{Fe}, \mathrm{Zn}$, and $\mathrm{Si}$ application on quantitative parameters of rice. International Journal of Farming and Allied Sciences, 3, 529533.

Keram, K.S., Sharma, B.L. and Sawarkar, D. (2012) Impact of $\mathrm{Zn}$ application on yield, quality, nutrients uptake and soil fertility in a medium deep black soil. International Journal of Science, Environment and Technology1, 563571.

Khan, M.A., Fuller, M.P. and Baloch, F.S. (2008) Effect of soil applied zinc sulphate on wheat (Triticum aestivum L.) grown on a calcareous soil in Pakistan. Research Communications,
$36,571-582$.

Lindsay, W.L. and Norvell, W.A. (1978) Development of DTPA soil testing for $\mathrm{Zn}, \mathrm{Fe}, \mathrm{Mn}$, and $\mathrm{Cu}$. Soil Science America Proc. Journal 42, 421-428.

Lowry, O.H., Rosebrough, N.J., Farr, A.L., and Randall, R.J. (1951) J. Biol. Chem193, 265 (The original method).

Nayyar, V.K., Sadana, U.S. and Takkar, T.N. (1985) Method and rates of application of Mn and its critical level for wheat following rice on coarse textured soils. Fertilizer Research8, 173-178.

Page, A.L., Millen. R. and Keeney, D.R. (1982) Methods of soil Analysis, Part 2-Chemical and microbiological properties, Second Edition. Agronomy Society of America Madison, WI.

Patel, K.P. and Singh, M.V. (2010) Management of micronutrients deficiencies for enhancing yield of crops. World congress of soil science, Soil solutions for changing world, Australia.

Patel, K.P., Patel, P.C., Patel, K.C. and Ramani, V.P. (2009) Effect of multimicronutrients mixture on yield, micronutrient uptake and quality of fodder maize (Zea mays L.) grown on Typic Ustochrepts soils of Anand. Gujarat Agricultural University Research Journal34, 44-48.

Sharma, B.L. and Bapat, P.N. (2000) Levels of micronutrient cations in various plant parts of wheat as influenced by zinc and phosphorus application. Journal of the Indian Society of Soil Science48, 130-134.

Singh, V. and Ram, N. (2005) Effect of 25 years of continuous fertilizer use on response to applied nutrients and uptake of micronutrients by ricewheat-cowpea system. Cereal Research Communications, 33, 589594. 
Soni, (1996) Influence of rates and methods of manganese application on yield and nutrition of wheat in a reclaimed sodic soil. The journal of Agricultural Science 127, 434-439.

Varshney, P., Singh, S.K. and Srivastava, P.C.
(2008) Frequency and rates of zinc application under hybrid rice-wheat sequence in a Mollisol of Uttarakhand. Journal of the Indian Society of Soil Science 56, 92-98.

\section{How to cite this article:}

Kadivala, V.H., V.P. Ramani and Patel, P.K. 2019. Effects of Multi-Micronutrient Mixture on Growth, Yield and Quality of the Summer Pearl Millet (Pennisetum glaucum L.). Int.J.Curr.Microbiol.App.Sci. 8(04): 783-790. doi: https://doi.org/10.20546/ijcmas.2019.804.086 